\title{
Potato Silver Scurf Affected by Tuber Seed Treatments and Locations, and Occurrence of Fungicide Resistant Isolates of Helminthosporium solani
}

\author{
Brad Geary, Brigham Young University, 269 WIDB, Provo, UT 84602; Dennis A. Johnson, Department of Plant \\ Pathology, Washington State University, P.O. Box 646430, Pullman 99164-6430; Philip B. Hamm, Department of \\ Botany and Plant Pathology, Oregon State University (OSU), Hermiston Agricultural Research and Extension Cen- \\ ter, P.O. Box 105, Hermiston 97838; Steve James, Central Oregon Experiment Station OSU, 850 N.W. Dogwood \\ Lane, Madras 97741; and Ken A. Rykbost, Klamath Falls Experiment Station OSU, 6941 Washburn Way, Klamath \\ Falls 97603
}

\begin{abstract}
Geary, B., Johnson, D. A., Hamm, P. B., James, S., and Rykbost, K. A. 2007. Potato silver scurf affected by tuber seed treatments and locations, and occurrence of fungicide resistant isolates of Helminthosporium solani. Plant Dis. 91:315-320.

The effectiveness of various seed-tuber treatments was evaluated for control of silver scurf on potato (Solanum tuberosum), caused by Helminthosporium solani, at four locations in Washington and Oregon using seed-tubers from the same source. Disease incidence was determined at harvest and following storage, and differed significantly among locations. The highest incidence of disease was observed at Redmond, OR and the lowest was at Hermiston, OR. Significantly less silver scurf occurred on progeny-tubers, regardless of location, when seed was treated with the fungicide treatments fludioxonil, fludioxonil + quintozene, azoxystrobin, or thiophanatemethyl + mancozeb compared with the nontreated control. A sample of $H$. solani from seed planted in the Columbia Basin of Washington and Oregon was assessed for resistance to thiabendazole (TBZ) and thiophanate-methyl (TPM). Sensitivity of 20 isolates of $H$. solani to TBZ was determined on V8 media amended with TBZ. Four isolates, selected as a subset from the 20 isolates tested for TBZ sensitivity, were tested for resistance to TPM, mancozeb, and TPM + mancozeb on amended V8 media. Isolates differed significantly in sensitivity to both chemicals. Thirteen isolates out of the 20 tested were resistant to TBZ. One out of the four subsets of isolates was resistant to both TBZ and TPM. TBZ sensitivity was not related to geographic origin of the isolates. Variation in resistance was evident on a small scale as seen with one resistant and one sensitive isolate collected from the same tuber. This is the first report that silver scurf incidence is affected by location despite the same tuber-seed source and also the first report of TBZ and TPM resistant isolates of $H$. solani from the Columbia Basin (Oregon and Washington) production area.
\end{abstract}

Additional keywords: silver scurf management

Silver scurf, caused by Helminthosporium solani Durieu \& Montagne, has been recently recognized as an important potato (Solanum tuberosum L.) disease because of fungicide-resistant strains, increased disease incidence, and financial losses from blemished tubers $(1,12,17,21)$. While this fungus only infects the periderm of tubers, it is particularly important to fresh market potato tubers because of the unsightly blemishes it can cause $(9,16,27)$. Blemishes consist of buff or brown lesions, becoming silvery in appearance when wet. Severe infections can completely obscure the periderm pigmentation of red and white colored cultivars (16). Water loss

Corresponding author: B. Geary

E-mail; brad_geary@byu.edu

Accepted for publication 25 September 2006.

DOI: 10.1094/PDIS-91-3-0315

(C) 2007 The American Phytopathological Society during storage through infected areas can result in up to $13 \%$ less yield, which affects grower returns whether the tubers are processed or marketed fresh $(16,18,25)$.

$H$. solani is considered a seedborne pathogen of potato $(15,16)$. Infected tubers are an important source of transmission of the pathogen and the main source of primary inoculum $(4,14,16,25)$. It spreads to progeny-tubers from lesions on infected seed pieces, and new infections can occur as soon as 10 weeks after planting $(8,15)$. Within 4 weeks the entire surface of the seed may be covered with lesions having large numbers of spores (16). Conidia from the lesions may infect progeny-tubers or remain in the soil and serve as inoculum infecting future potato crops; however, the role of soilborne inoculum on silver scurf incidence is not conclusive.

Diseased tubers taken into storage can result in rapid pathogen spread to noninfected seed-tubers (9). Infected areas become sporulating lesions that expand across the tuber and to other neighboring tubers (26). Conidia produced in storage may become airborne and dispersed throughout the storage by the ventilation system (27). Rodriguez et al. (27) estimated that up to 24,000 conidia were moved through a ventilation system per day in North Dakota. The number of conidia increased with time in storage due to increasing levels of incidence of infection and an increase from mechanical (trucks, conveyor belts, etc.) activity when potatoes are removed (27). After tubers are removed from storage, the fungus can survive within the storage facility and infect next year's tubers (9).

Control of $H$. solani is difficult because the fungus survives and spreads both in the field and in storage. However, seed-tuber treatments can limit disease incidence. A number of seed treatments have been shown to be effective in limiting disease incidence, including thiabendazole (TBZ), imazalil, prochloraz, prochloraz manganese chloride, thiophanate-methyl (TPM) with mancozeb, captan with mancozeb, fludioxonil, and benomyl (3,6,9,11,15, $28,29)$. Organic and inorganic salts have been successfully used as postharvest applications for silver scurf control, and may work as seed treatments because they significantly limited $H$. solani sporulation in storage (24). Control of silver scurf is primarily due to the inhibition of sporulation on seed-tubers after planting, regardless of whether chemical or salt seed treatments are used (15). However, inconsistencies of seed treatments to control silver scurf have been reported $(6,9)$ and may be a result of location variations, for example temperature, soil moisture, soil microbes, preexisting soilborne inoculum, and soil type. Due to the diverse planting locations of potato, it is possible that field location could influence silver scurf development, but influential factors are not clearly identified and have not been investigated.

Resistance to TBZ and TPM has also been reported, and these resistant strains can result in high disease incidence on seed-tubers treated with these compounds $(12,17)$. In Alberta, Canada, the use of TBZ as a seed treatment appears to have selected TBZ-resistant isolates (1). Although the level of resistance differed 
among isolates, those from southern Alberta were more resistant and had a larger ratio of resistance to sensitivity than those from north-central Alberta (1). TBZ was used more frequently in southern Alberta, which may account for the increased resistance in that area, but the quantity of annual treatments needed to facilitate selection is not known (13). Resistant TBZ and TPM isolates have not been reported from the Columbia Basin of Washington and Oregon, but are expected due to an increase in silver scurf incidence and the large quantities of seed-tubers brought in from other potato-producing areas. If resisand importance to the silver scurf problem needs to be documented.

Silver scurf has become an increasingly important potato disease in the Columbia Basin of Washington and Oregon because of the financial losses from blemished tubers. Reports of differing effectiveness of seed-tuber treatments and resistance to seed treatments containing TBZ and TPM in other areas of the United States and Canada have prompted research on the effectiveness of seed treatments used in the region $(6,9,13)$. Therefore, the purposes of this study were to determine: (i) the effectiveness and consistency of seed-tuber treatments to control silver scurf in progeny-tubers when grown in differing potatoproducing areas, and (ii) the incidence and possible importance of TBZ and TPM resistance in the Columbia Basin of Washington and Oregon.

\section{MATERIALS AND METHODS}

Seed-piece fungicide evaluations. Fungicides were evaluated for their effects on silver scurf in fields at four locations near Othello, WA, Redmond, OR, Klamath Falls, OR, and Hermiston, OR, in both 1998 and 1999. Research fields did not have potatoes previously for 3,2 , and 3 tant isolates are present, their frequency

years for Othello, Klamath Falls, and Hermiston, respectively, and never had potatoes previously at Redmond. Othello's crop rotation leading up to the field that had potatoes in 1998 and 1999 was: 1997 corn, 1996 corn, 1995 barley, and 1998 wheat, 1997 corn, 1996 beans, respectively. Klamath Falls had a wheat-barley rotation for the 2 years leading up to both fields of potatoes. Hermiston had a barleywheat-oats rotation for the 3 years leading up to both fields of potatoes. Redmond was previously cropped with dryland wheat alternated with fallow for many years. Locations represented the major potatoproducing regions of Washington and Oregon. A certified seed lot of cultivar Russet Norkotah was selected each year from the same grower located in Oregon, confirmed to have silver scurf, then treated with each of eight fungicide programs for the Washington location in 1998 and nine in 1999, and each of nine fungicide programs for the Oregon locations in both years. Control seed-pieces were not treated. Experiments at each location were designed as randomized complete blocks with four replications. Standard commercial potato production practices were used in all fields (7).

Seed for all four locations was cut into two-ounce seed-pieces and then treated by placing the seed-pieces into a plastic pail with the appropriate rate of fungicide, fitted with a lid and then gently mixed, bagged by replication, and sent to the field for planting. Planting, defoliation, and harvest dates for each location are given in Table 1. Individual plots at all locations were single rows $9.15 \mathrm{~m}$ long, with seedpiece spacing $25 \mathrm{~cm}$ within the row and 86 $\mathrm{cm}$ between rows. Fungicide treatments were the same at all locations except that fludioxonil + quintozene was not used at Othello in 1998. All fungicide treatments, trade names, manufacturers, and rates per $\mathrm{kg}$ of potatoes are given in Table 2 .

Table 1. Planting, defoliation, and harvesting dates of potatoes planted in the field for fungicide seedpiece evaluations

\begin{tabular}{|c|c|c|c|c|c|c|}
\hline \multirow[b]{2}{*}{ Location } & \multicolumn{2}{|c|}{ Planted } & \multicolumn{2}{|c|}{ Defoliated } & \multicolumn{2}{|c|}{ Harvested } \\
\hline & 1998 & 1999 & 1998 & 1999 & 1998 & 1999 \\
\hline Othello, WA & $28 \mathrm{Apr}$ & 5 May & $9 \mathrm{Sep}$ & $12 \mathrm{Sep}$ & $24 \mathrm{Sep}$ & $1 \mathrm{Oct}$ \\
\hline Redmond, OR & 16 May & 15 May & $7 \mathrm{Sep}$ & $16 \mathrm{Sep}$ & $23 \mathrm{Sep}$ & 2 Oct \\
\hline Klamath Falls, OR & 9 June & 20 May & $19 \mathrm{Sep}$ & $6 \mathrm{Sep}$ & 12 Oct & $21 \mathrm{Sep}$ \\
\hline Hermiston, OR & $8 \mathrm{Apr}$ & $12 \mathrm{Apr}$ & 11 Sep & $20 \mathrm{Sep}$ & $26 \mathrm{Sep}$ & 7 Oct \\
\hline
\end{tabular}

Silver scurf incidence was assigned as the percentage of tubers infected and was obtained by collecting 25 tubers per replication from each treatment at each location immediately after harvest and 4 months after storage at 9 to $10^{\circ} \mathrm{C}$ (spring). Tubers grown in Othello were analyzed for silver scurf by washing with water until dirt is removed then soaking for $10 \mathrm{~min}$ in a $10 \%$ solution consisting of $90 \%$ hot water $\left(70^{\circ} \mathrm{C}\right)$ and $10 \%$ sodium hypochlorite $(\mathrm{NaOCl}, 6.15 \%)$. Following disease evaluation, the tubers were discarded. At Redmond, Hermiston, and Klamath Falls, tubers were washed, placed in bags with small holes, then placed in covered boxes and allowed to incubate for 3 weeks with weekly moistening in the dark at $20^{\circ} \mathrm{C}$, then screened for silver scurf. A dissecting microscope was used to confirm silver scurf infections. Data for disease incidence were analyzed by ANOVA using the GLM procedure of SAS (SAS Institute, Cary, NC). Treatment means were compared using Fisher's protected LSD with a critical value of $P \leq 0.05$.

Sensitivity of $H$. solani to TBZ, TPM, and mancozeb. Isolates collected for fungicide sensitivity experiments came from certified potato seed-tubers that had been produced by commercial seed growers in Washington, Idaho, Montana, Wyoming, Oregon, Nebraska, Minnesota, and North Dakota in the United States, and in Alberta and British Columbia in Canada. Seed tubers had been submitted to the 1998 potato seed lot performance trials conducted at the Washington State University Agricultural Research Station near Othello. Twenty isolates of $H$. solani were collected according to origin of seed-tuber (Table 3). Isolates were obtained by incubating tubers for 1 week in a moist chamber near $100 \%$ relative humidity at $25^{\circ} \mathrm{C}$. Infected tubers were selected and conidia were removed from sporulating lesions with a wire loop and spread on potato dextrose agar (Difco Laboratories, Detroit, MI). Twenty-four to $48 \mathrm{~h}$ later, individual conidia that germinated were randomly selected and transferred to V8 agar amended with streptomycin sulfate at 200 $\mathrm{mg} / \mathrm{liter}$. Isolates were given an identification code and maintained on V8 agar at $25^{\circ} \mathrm{C}$ in the dark (10).

Two separate experiments tested $\mathrm{H}$. solani sensitivity to TBZ, TPM, mancozeb,

Table 2. Rates, manufacturers, trade and common names of salts, fungicides, and surfactants used in tests to control silver scurf on potato tubers ${ }^{\mathrm{Z}}$

\begin{tabular}{|c|c|c|c|}
\hline Active ingredient & Trade name & Rate & Manufacturer \\
\hline-- & Sodium Carbonate & $0.2 \mathrm{M}$ & Fisher Scientific, Springfield, NJ \\
\hline Potassium sorbate & Sorbic Acid (1.6\% a.i.) & $0.45 \mathrm{~kg} / 45 \mathrm{~kg}$ & Sigma Chemical Co., St. Louis, MO \\
\hline Azoxystrobin & Quadris $2.08 \mathrm{~F}$ & $6 \mathrm{ml} / \mathrm{liter}$ & Syngenta, Greensboro, NC \\
\hline Fludioxonil & Maxim $0.5 \%$ & $0.23 \mathrm{~kg} / 45 \mathrm{~kg}$ & Syngenta, Greensboro, NC \\
\hline Thiophanate-methyl & Tops $5,5 \%$ & $0.45 \mathrm{~kg} / 45 \mathrm{~kg}$ & Gustafson, McKinney, TX \\
\hline Mancozeb & Dithane $75 \mathrm{DF}$ & $0.23 \mathrm{~kg} / 45 \mathrm{~kg}$ & Dow Agrosciences, Indianapolis, IN \\
\hline Thiophanate-methyl + mancozeb & Tops MZ $(2.5 \%, 6.0 \%$ a.i. $)$ & $0.34 \mathrm{~kg}$ and $0.45 \mathrm{~kg} / 45 \mathrm{~kg}$ & Gustafson, McKinney, TX \\
\hline Quintozene & PCNB (34\% a.i.) & $0.75 \mathrm{~kg} / 305 \mathrm{~m}$ & Gustafson, McKinney, TX \\
\hline
\end{tabular}

z All were seed treatments applied following cutting except quintozene, which was applied in-furrow. 
and TPM + mancozeb (a combination of $0.295 \mathrm{~g}$ of TPM with $0.705 \mathrm{~g}$ of mancozeb) (Table 2). In both experiments, each isolate was grown on V8 agar amended with the appropriate fungicide at $0,1,10$, and 100 $\mu \mathrm{g} / \mathrm{ml}$ of medium. Stock solutions of technical grade TBZ, TPM, mancozeb, and TPM + mancozeb were mixed in $\operatorname{DMF}(N, N$,dimethyl formamide; Fisher Chemicals, Springfield, NJ) at $1 \mathrm{~g} / 200 \mathrm{ml}$ to dissolve the fungicide. Each fungicide rate was added to V8 agar cooled to $60^{\circ} \mathrm{C}$. Equivalent amounts of DMF $(0,0.2,2$, and 20 $\mathrm{ml} /$ liter) were added to V8 agar for controls. A control treatment with no fungicide or DMF was included. Mycelial plugs $(5 \mathrm{~mm}$ diameter) from 4- to 6-week-old colonies were placed on the amended agar. Radial growth was determined by taking the mean of two measurements at 90 degrees to each other after incubation for 14, 28, and 42 days at $25^{\circ} \mathrm{C}$ in the dark. Area under the colony growth curve (30) was used to determine fungicide sensitivity by finding those isolates whose colony diameter on fungicide-amended media was reduced by $50 \%\left(\mathrm{EC}_{50}\right)$ or more at the treatment rate of $10 \mu \mathrm{g} / \mathrm{ml}$, when compared to the same isolate on media amended with an equal amount of DMF (13).

In the first experiment, 20 isolates of $H$. solani (Table 3 ) were tested for sensitivity to TBZ. Sensitivity was evaluated by arranging treatments in a $20 \times 4 \times 4$ (isolate $\times$ DMF level $\times$ TBZ concentration) factorial design with four replications, and the experiment was repeated once. When collecting isolates for this study, it was observed that some single conidial colonies from the same tuber appeared morphologically dissimilar. To determine if these colonies differed in sensitivity to TBZ, three pairs of isolates (1a and $1 \mathrm{~b}, 5 \mathrm{a}$ and $5 \mathrm{~b}, 12 \mathrm{a}$ and $12 b$ ) from three separate tubers, each tuber pair from a different seed lot, were included in the first experiment. In the second experiment, TPM, mancozeb, and TPM + mancozeb sensitivity was evaluated by placing treatments in a $4 \times 4 \times 4$ (isolate $\times$ DMF level $\times$ fungicide concentration) factorial design with five replications, and the experiment was repeated once. Four randomly selected isolates $(14,25,11$, and $1 \mathrm{~b})$ were used to test sensitivity.

Data from the seed-piece fungicide evaluations were analyzed by analysis of variance using the MIXED procedure of SAS (version 9.1). Treatment means were adjusted using Tukey-Kramer and compared using pair-wise comparison with a critical value of $P \leq 0.05$. Sensitivity of $H$. solani to TBZ, TPM, and mancozeb was analyzed by analysis of variance using the GLM procedure of SAS. Treatment means were compared using Fisher's protected LSD with a critical value of $P<0.05$.

\section{RESULTS}

Seed-piece fungicide evaluations. Silver scurf incidence on progeny-tubers differed significantly among the four locations in both years (Table 4). A higher incidence of disease was observed at harvest at Redmond than at any other location. More silver scurf occurred at Klamath Falls than at either Hermiston or Othello (Table 4). After storage, highest levels were found on tubers that had been grown in Redmond, less from Klamath Falls and Othello, with the lowest levels from Hermiston. Silver scurf incidence from nontreated plots increased following storage for all four locations (Table 4).

The effects of the fungicide treatments varied significantly according to location and time of disease assessment $(P \leq 0.05)$. Over the 2 years of the seed treatment portion of this study, different groups of seed-tubers were evaluated 15 different times. Seed-tubers treated with either fludioxonil + quintozene, TPM + mancozeb $(0.45 \mathrm{~kg} / 45 \mathrm{~kg})$, azoxystrobin, or fludioxonil had significantly $(P \leq 0.05)$ less disease incidence than the untreated control for progeny-tubers from Redmond for both years at harvest and in the spring (Table 5). Disease incidence was also lower than the control with fludioxonil + quintozene progeny-tubers from Othello, the 1999 spring sample, and with TPM + mancozeb $(0.34 \mathrm{~kg} / 45 \mathrm{~kg})$ from Redmond, the 1998 harvest sample (Table 5). Except for the spring sample from Klamath Falls in 1999, the same treatments listed above were either significantly or numerically lower than the untreated control regardless of sampling times or locations. Treatments with TPM, sorbic acid, mancozeb, and sodium carbonate were not significantly $(P \leq 0.05)$ different from the untreated control at any location or sampling time (Table 5). Silver scurf increase in storage for the fungicide treatments did not differ significantly (data not shown).

Table 3. Origin of Helminthosporium solani isolates, location, and cultivar used to evaluate sensitivity to fungicides and colony growth rate

\begin{tabular}{|c|c|c|}
\hline Isolate ${ }^{y}$ & $\begin{array}{l}\text { State or } \\
\text { province }\end{array}$ & Cultivar \\
\hline $1 \mathrm{a}, 1 \mathrm{~b}, 4,10,17$ & WA & Russet Norkotah \\
\hline $5 a, 5 b$ & MT & Russet Norkotah \\
\hline 8,11 & $\mathrm{ALB}^{\mathrm{z}}$ & Russet Norkotah \\
\hline $12 a, 12 b$ & WA & Yukon Gold \\
\hline 14 & ID & Russet Burbank \\
\hline 15 & MT & Russet Burbank \\
\hline 18 & ID & Ranger Russet \\
\hline 19 & WY & Russet Norkotah \\
\hline 20 & $\mathrm{OR}$ & Russet Norkotah \\
\hline 21 & $\mathrm{NE}$ & Shepody \\
\hline 22 & MN & Atlantic \\
\hline 25 & ND & Russet Norkotah \\
\hline 26 & $\mathrm{BC}^{\mathrm{z}}$ & Atlantic \\
\hline
\end{tabular}

${ }^{\mathrm{y}}$ Isolates with the same number but different letter indicate they came from the same potato tuber but the colonies were different morphologically.

${ }^{\mathrm{z}}$ Isolate from either Alberta or British Columbia, Canada.
Sensitivity of $\boldsymbol{H}$. solani to TBZ, TPM, and mancozeb. Isolates $4,5 \mathrm{a}, 5 \mathrm{~b}, 8,12 \mathrm{a}$, $15,17,18,19,21,22,25$, and 26 were resistant to TBZ, and isolates $1 \mathrm{a}, 1 \mathrm{~b}, 10$, $11,12 \mathrm{~b}, 14$, and 20 were sensitive (Table $6)$. All isolates that were sensitive did not grow at $10 \mu \mathrm{g} / \mathrm{ml}$ (Table 6). Isolates 14,11 , and $1 \mathrm{~b}$ were sensitive to TPM, and isolate 25 was resistant. All isolates were resistant to mancozeb, and only isolate 25 was resistant to both TPM and mancozeb and the combination treatment TPM + mancozeb (Table 7). Growth of some isolates of $H$. solani significantly $(P \leq 0.05)$ decreased when concentrations of DMF were 10 $\mu \mathrm{g} / \mathrm{ml}$, and growth of all isolates was retarded at $100 \mu \mathrm{g} / \mathrm{ml}$.

One of the three pairs of single conidial colonies from the same tuber that were dissimilar morphologically was different in its sensitivity to TBZ. Isolate $12 \mathrm{a}$ was resistant while $12 \mathrm{~b}$ was sensitive to TBZ. Isolates $1 \mathrm{a}$ and $1 \mathrm{~b}$, and $5 \mathrm{a}$ and $5 \mathrm{~b}$ did not differ in sensitivity to TBZ.

\section{DISCUSSION}

Differences in disease levels at the four field locations indicate that geographical location influenced the development of silver scurf. This was not expected since initial inoculum for silver scurf in the field is predominately tuber-borne and more important than the soil environment given sufficient moisture and adequate temperature for infection and plant growth $(14,16)$. However, disease development varied among locations, and this variation may have been due to soil microbes, amount of preexisting soilborne inoculum, soil type, soil moisture associated with irrigation or rain, and soil temperature. Soil microbes antagonistic to $H$. solani may have been present and had a limited effect on disease development at the locations where potatoes had been previously grown, and may not have been present at Redmond (which

Table 4. Silver scurf incidence on progenytubers of Russet Norkotah when seed-tubers were planted without fungicide treatments at four locations in Washington and Oregon in 1998 and $1999^{\mathrm{z}}$

\begin{tabular}{lcc}
\hline Location & $\begin{array}{c}\text { Harvest } \\
\text { incidence }\end{array}$ & $\begin{array}{c}\text { Spring } \\
\text { incidence }\end{array}$ \\
\hline Redmond, OR & $44.0 \mathrm{a}$ & $51.2 \mathrm{a}$ \\
Hermiston, OR & $10.6 \mathrm{c}$ & $11.0 \mathrm{c}$ \\
Klamath Falls, OR & $20.8 \mathrm{~b}$ & $32.6 \mathrm{~b}$ \\
Othello, WA & $8.0 \mathrm{c}$ & $24.4 \mathrm{~b}$ \\
\hline
\end{tabular}

z Values were obtained from 25 tubers per replication with four replications at each location, samples were obtained from nontreated control plots. Treatment means were compared using Fisher's LSD with a critical value of $P \leq 0.05$, disease incidences followed by the same letter (in a column) are not significantly different from each other. There were no significant interactions between years and locations; therefore data from 1998 and 1999 were combined. Incidence of silver scurf was determined as percentage of tubers infected. 
had the greatest disease incidences) where potatoes had not been previously grown. However, the presence of such soil microbes was not verified in this test.

Variation in the amount of soilborne inoculum is not thought to be an important factor affecting silver scurf incidence (4). $H$. solani has been reported to survive at least 1 year in New York soils, such that some disease could develop from soilborne inoculum (22). Residues of crops commonly planted as rotational crops in potato fields have supported growth and survival of $H$. solani when tested in vitro (22). Rotational crops in this study were similar at all four locations, but the disease levels were not similar. Previous crop residues may have allowed survival of some soilborne inoculum, but it was not a significant effect on disease levels because of the differences observed near Redmond. Disease symptoms have been reported on progeny-tubers from disease free nuclear seed in Alberta, again indicating the presence of soilborne inoculum (1). However, in the four locations of this study, potatoes had not been grown for at least 2 years, which should have minimized any soilborne inoculum $(1,8)$. The highest level of silver scurf occurred where potatoes had never been previously grown (Redmond). Soilborne inoculum at Redmond could have been blown in or brought in by equipment, but the possibility that introduced inoculum noticeably influenced disease incidence is unlikely. More work is needed to understand the biology and survival of $H$. solani and the influence of soil microbes and edaphic factors, particularly considering that the
Redmond location had the highest incidence levels.

Incidence of silver scurf on progenytubers was lowered with the use of seed treatments. Cayley et al. (3) and Jellis and Taylor (15) reported a decrease in silver scurf on progeny-tubers following seed treatments with the fungicides imazalil, benomyl, and TBZ. Tsror and Peretz-Alon (29) also reported fewer diseased progenytubers when seed-tubers were treated with fludioxonil, prochloraz + zinc, propineb, and mancidan. Azoxystrobin and imazalil were less effective in disease control than the aforementioned fungicides but were significantly better than nontreated (29). Results from the current study similarly indicate a seed treatment on commercially produced seed-tubers using fludioxonil, fludioxonil + quintozene, azoxystrobin, or

Table 5. Silver scurf incidence on progeny-tubers of Russet Norkotah when seed-tubers were treated with various compounds or not treated at four locations in Washington and Oregon in 1998 and $1999^{x}$

\begin{tabular}{|c|c|c|c|c|c|c|c|c|c|c|c|c|c|c|c|c|}
\hline \multirow[b]{3}{*}{ Seed treatment } & \multicolumn{8}{|c|}{1998} & \multicolumn{8}{|c|}{1999} \\
\hline & \multicolumn{2}{|c|}{$\begin{array}{c}\text { Redmond, } \\
\text { OR }\end{array}$} & \multicolumn{2}{|c|}{$\begin{array}{c}\text { Hermiston, } \\
\text { OR }\end{array}$} & \multicolumn{2}{|c|}{$\begin{array}{l}\text { Klamath } \\
\text { Falls, OR }\end{array}$} & \multicolumn{2}{|c|}{$\begin{array}{l}\text { Othello, } \\
\text { WA }\end{array}$} & \multicolumn{2}{|c|}{$\begin{array}{c}\text { Redmond, } \\
\text { OR }\end{array}$} & \multicolumn{2}{|c|}{$\begin{array}{c}\text { Hermiston, } \\
\text { OR }\end{array}$} & \multicolumn{2}{|c|}{$\begin{array}{l}\text { Klamath } \\
\text { Falls, OR }\end{array}$} & \multicolumn{2}{|c|}{$\begin{array}{c}\text { Othello, } \\
\text { WA }\end{array}$} \\
\hline & $\begin{array}{l}\text { Har- } \\
\text { vest }^{y}\end{array}$ & Spring ${ }^{y}$ & $\begin{array}{l}\text { Har- } \\
\text { vest }\end{array}$ & Spring & $\begin{array}{l}\text { Har- } \\
\text { vest }\end{array}$ & Spring & $\begin{array}{l}\text { Har- } \\
\text { vest }\end{array}$ & Spring & $\begin{array}{l}\text { Har- } \\
\text { vest }\end{array}$ & Spring & $\begin{array}{l}\text { Har- } \\
\text { vest }\end{array}$ & Spring & $\begin{array}{l}\text { Har- } \\
\text { vest }\end{array}$ & Spring & $\begin{array}{l}\text { Har- } \\
\text { vest }\end{array}$ & Spring \\
\hline $\begin{array}{l}\text { Fludioxonil + } \\
\text { quintozene } \\
\text { Mancozeb + TPM }\end{array}$ & $9 \mathrm{~b}$ & $13 \mathrm{~d}$ & $1 \mathrm{~b}$ & $1 \mathrm{ab}$ & $3 \mathrm{ab}$ & $1 \mathrm{c}$ & na & na & $11 \mathrm{c}$ & $17 \mathrm{c}$ & $6 \mathrm{a}$ & $12 \mathrm{a}$ & $13 \mathrm{a}$ & $41 \mathrm{ab}$ & $8 \mathrm{a}$ & $7 \mathrm{~b}$ \\
\hline $\begin{array}{c}0.34 \mathrm{~kg} \\
\text { Mancozeb + TPM }\end{array}$ & $14 \mathrm{~b}$ & $31 \mathrm{bcd}$ & $9 a b$ & $4 \mathrm{ab}$ & $7 \mathrm{ab}$ & $5 \mathrm{bc}$ & na & $21 \mathrm{~b}$ & $23 \mathrm{bc}$ & $38 \mathrm{bc}$ & $4 \mathrm{a}$ & $7 \mathrm{a}$ & $21 \mathrm{a}$ & $31 \mathrm{ab}$ & $3 \mathrm{a}$ & $10 \mathrm{ab}$ \\
\hline $0.45 \mathrm{~kg}$ & $14 \mathrm{~b}$ & $14 \mathrm{~d}$ & $9 a b$ & $2 a b$ & $10 \mathrm{ab}$ & $7 \mathrm{abc}$ & na & $25 a b$ & $13 \mathrm{c}$ & $23 \mathrm{c}$ & $2 \mathrm{a}$ & $6 \mathrm{a}$ & $19 \mathrm{a}$ & $26 \mathrm{ab}$ & $5 \mathrm{a}$ & $11 \mathrm{ab}$ \\
\hline Azoxystrobin & $10 \mathrm{~b}$ & $13 \mathrm{~d}$ & $8 \mathrm{ab}$ & $0 \mathrm{~b}$ & $3 \mathrm{ab}$ & $2 \mathrm{bc}$ & na & $22 \mathrm{ab}$ & $12 \mathrm{c}$ & $25 \mathrm{c}$ & $2 \mathrm{a}$ & $5 \mathrm{a}$ & $16 \mathrm{a}$ & $22 \mathrm{ab}$ & $6 \mathrm{a}$ & $13 \mathrm{ab}$ \\
\hline Fludioxonil & $20 \mathrm{~b}$ & $17 \mathrm{~cd}$ & $9 \mathrm{ab}$ & $2 \mathrm{ab}$ & $1 \mathrm{~b}$ & $6 a b c$ & na & $19 \mathrm{~b}$ & $15 \mathrm{c}$ & $17 \mathrm{c}$ & $2 \mathrm{a}$ & $2 \mathrm{a}$ & $10 \mathrm{a}$ & $19 \mathrm{~b}$ & $4 \mathrm{a}$ & $9 \mathrm{ab}$ \\
\hline TPM & $53 \mathrm{a}$ & $56 \mathrm{ab}$ & $22 \mathrm{ab}$ & $23 \mathrm{a}$ & $19 \mathrm{ab}$ & $16 a b c$ & na & $35 \mathrm{a}$ & $59 \mathrm{a}$ & $60 \mathrm{ab}$ & $21 \mathrm{a}$ & $8 \mathrm{a}$ & $27 \mathrm{a}$ & $47 \mathrm{ab}$ & $11 \mathrm{a}$ & $28 \mathrm{ab}$ \\
\hline Sorbic acid & $45 \mathrm{a}$ & $45 \mathrm{abc}$ & $10 \mathrm{ab}$ & $10 \mathrm{ab}$ & $17 \mathrm{ab}$ & $26 \mathrm{ab}$ & na & $21 \mathrm{~b}$ & $75 a$ & $76 \mathrm{a}$ & $11 \mathrm{a}$ & $12 \mathrm{a}$ & $27 \mathrm{a}$ & $33 \mathrm{ab}$ & $9 \mathrm{a}$ & $26 \mathrm{ab}$ \\
\hline Mancozeb & $50 \mathrm{a}$ & $47 \mathrm{ab}$ & $23 \mathrm{a}$ & $18 \mathrm{ab}$ & $22 \mathrm{ab}$ & $25 a b c$ & na & $28 \mathrm{ab}$ & $63 \mathrm{a}$ & $78 \mathrm{a}$ & $11 \mathrm{a}$ & $27 \mathrm{a}$ & $47 \mathrm{a}$ & $59 \mathrm{ab}$ & $13 \mathrm{a}$ & $18 \mathrm{ab}$ \\
\hline Sodium carbonate & $54 \mathrm{a}$ & $68 \mathrm{a}$ & $11 \mathrm{ab}$ & $11 \mathrm{ab}$ & $25 \mathrm{a}$ & $30 \mathrm{a}$ & na & $30 \mathrm{ab}$ & $55 \mathrm{a}$ & $71 \mathrm{a}$ & $14 \mathrm{a}$ & $14 \mathrm{a}$ & $44 \mathrm{a}$ & $74 \mathrm{a}$ & $3 \mathrm{a}$ & $21 a b$ \\
\hline Nontreated control & $52 \mathrm{a}$ & $59 \mathrm{ab}$ & $16 \mathrm{ab}$ & $9 \mathrm{ab}$ & $14 \mathrm{ab}$ & $25 \mathrm{abc}$ & na & $32 \mathrm{ab}$ & $50 \mathrm{ab}$ & $59 \mathrm{ab}$ & $14 \mathrm{a}$ & $18 \mathrm{a}$ & $23 \mathrm{a}$ & $31 \mathrm{ab}$ & $12 \mathrm{a}$ & $32 \mathrm{a}$ \\
\hline
\end{tabular}

${ }^{x}$ Values were obtained from 25 tubers per replication with four replications at each location. Treatment means were adjusted by Tukey-Kramer and compared using pair-wise comparisons with a critical value of $P \leq 0.05$, disease incidences followed by the same letter (in a column) are not significantly different from each other. Incidence of silver scurf was determined as the percentage of tubers infected.

${ }^{y}$ Harvest (end of September, first part of October) indicates collection of potato tubers and data immediately after the growing season, spring (February) indicates data collection on tubers that were stored for 4 months following harvest the previous fall.

z Thiophanate-methyl.

Table 6. Area under colony expansion curve of 20 Helminthosporium solani isolates on V8 media amended with thiabendazole (TBZ) compared with growth on V8 media not amended

\begin{tabular}{|c|c|c|c|c|c|c|c|c|c|c|c|c|c|c|c|c|c|c|c|c|}
\hline \multirow[b]{2}{*}{ Treatment } & \multicolumn{20}{|c|}{ Isolate $^{\mathrm{x}}$} \\
\hline & 1a & $1 b^{y}$ & 4 & $5 \mathbf{a}$ & $5 b^{y}$ & 8 & 10 & 11 & $12 \mathbf{a}$ & $12 b^{y}$ & 14 & 15 & 17 & 18 & 19 & 20 & 21 & 22 & 25 & 26 \\
\hline \multicolumn{21}{|c|}{ First experiment } \\
\hline $1 \mu \mathrm{g}$ & 83 & 90 & 98 & 97 & 97 & 98 & 38 & 92 & 101 & 76 & 92 & 94 & 101 & 96 & 99 & 95 & 99 & 101 & 98 & 97 \\
\hline $10 \mu \mathrm{g}$ & 0 & 0 & 92 & 85 & 80 & 91 & 0 & 0 & 80 & 0 & 0 & 81 & 91 & 81 & 89 & 0 & 82 & 95 & 86 & 80 \\
\hline $100 \mu \mathrm{g}$ & 0 & 0 & 0 & 0 & 0 & 0 & 0 & 0 & 0 & 0 & 0 & 0 & 0 & 0 & 0 & 0 & 0 & 0 & 0 & 0 \\
\hline Response $^{\mathrm{z}}$ & sen & sen & res & res & res & res & sen & sen & res & sen & sen & res & res & res & res & sen & res & res & res & res \\
\hline \multicolumn{21}{|c|}{ Repeated experiment } \\
\hline $1 \mu \mathrm{g}$ & 83 & 93 & 107 & 97 & 96 & 105 & 63 & 96 & 96 & 82 & 92 & 97 & 103 & 92 & 101 & 91 & 85 & 96 & 92 & 91 \\
\hline $10 \mu \mathrm{g}$ & 0 & 0 & 88 & 71 & 73 & 99 & 0 & 0 & 81 & 0 & 0 & 84 & 80 & 83 & 81 & 0 & 81 & 95 & 89 & 69 \\
\hline $100 \mu \mathrm{g}$ & 0 & 0 & 0 & 0 & 0 & 0 & 0 & 0 & 0 & 0 & 0 & 0 & 0 & 0 & 0 & 0 & 0 & 0 & 0 & 0 \\
\hline Response $^{\mathrm{Z}}$ & sen & sen & res & res & res & res & sen & sen & res & sen & sen & res & res & res & res & sen & res & res & res & res \\
\hline
\end{tabular}

${ }^{\mathrm{x}}$ Values are the percent growth of each fungicide treatment compared with the $0 \mathrm{ppm}$ control containing DMF ( $N, N$,-dimethyl formamide). Growth of the $H$. solani isolates was determined by Area Under Colony Expansion Curve (AUCEC) and represents colony expansion over time. AUCEC was used to determine fungicide sensitivity and was calculated by plotting the estimated proportion of growth against time and calculating the area under the plotted line as is done when determining the area under the disease progress curve (30). Percent growth is the treatment AUCEC in relation to the DMF control AUCEC.

${ }^{y}$ Isolates with the same number came from the same tuber but were morphologically distinct.

${ }^{\mathrm{z}}$ Response indicates sensitivity to $\mathrm{TBZ}$, sensitive $=$ sen and resistant $=$ res. Sensitivity was determined by a decrease in colony growth by $50 \%$ or more $\left(\mathrm{EC}_{50}\right)$ at the TBZ treatment rate of $10 \mu \mathrm{g} / \mathrm{ml}$ when compared with colonies on agar amended with equal amounts of DMF. 
$\mathrm{TPM}+$ mancozeb (both rates) suppressed tubers. The results herein also indicate, regardless of the apparent differences in disease pressure due to location, these products were effective in controlling $H$. solani.

Salts (sodium carbonate and sorbic acid) were not significantly better in decreasing disease compared with the untreated control in any samples. The potential use of these products as seed treatments in the field for the control of silver scurf does not seem likely; yet their use as seed treatments should not be dismissed because studies are needed to evaluate other salts. Use of the salts as postharvest treatments might work well into a silver scurf control program because sporulation from infections that occurred during the growing year would be reduced, therefore decreasing disease incidence on seed-tubers.

Since silver scurf, like other diseases of potatoes, is a seedborne disease $(15,16)$, control of this disease begins with the seed grower and their applications of seed treatments. However, consecutive seasonal applications of a seed treatment would be needed when progeny-tubers will be used as seed-tubers. Jellis and Taylor (16) reported that seed-tubers must be treated every year in order to maintain a relatively disease-free seed-tuber stock. If not, seed with low disease incidences produced from treated seed gave rise to progeny that had similar amounts of disease to tubers grown from infected nontreated seed. Combinathe incidence of silver scurf on progenythey do limit sporulation (24), and more

tions of seed treatments with different modes of action should be used or alternate modes of action each year to decrease the risks of developing resistance (21).

Fungicidal seed treatments applied at planting did not significantly influence the development of silver scurf during storage in the current study. Postharvest fungicide applications are needed to control the spread of silver scurf during storage, as was observed in research from South Africa when prochloraz and prochloraz manganese chloride were applied as postharvest treatments (6). As time in storage lengthens, the level of silver scurf increases and treatments immediately before storage or during storage may be required to minimize silver scurf spread $(23,27)$.

The continuous use of a single site mode of action seed treatment may select for resistant isolates of $H$. solani (5). Bain et al. (1) reported that TBZ was used more frequently in southern Alberta than in north-central Alberta, and individual isolates from the southern region were more resistant and populations had a larger ratio of resistant to sensitive isolates. Others have also reported TBZ resistance as well as TPM resistance $(12,17,21)$, but there have been no reports of resistant isolates occurring in the Columbia Basin of Washington and Oregon. From the 20 isolates tested in the current study, 13 were found to be resistant to TBZ. Of those 13, four isolates originated from Washington, while the other nine isolates were collected from seed-tubers originating from other states/provinces. Among the four isolates

Table 7. Percent growth of four Helminthosporium solani isolates on V8 media amended with thiophanate-methyl (TPM), mancozeb, and TPM + mancozeb compared with growth on V8 media without the respective fungicides

\begin{tabular}{|c|c|c|c|c|}
\hline \multirow{2}{*}{$\begin{array}{l}\text { Fungicide } \\
\text { Concentration }\end{array}$} & \multicolumn{4}{|c|}{ Isolate $^{y}$} \\
\hline & 14 & 11 & 25 & $1 \mathrm{~b}$ \\
\hline \multicolumn{5}{|l|}{$\mathrm{TPM}$} \\
\hline $1 \mu \mathrm{g}$ & 44 & 24 & 101 & 1 \\
\hline $10 \mu \mathrm{g}$ & 1 & 0 & 100 & 3 \\
\hline $100 \mu \mathrm{g}$ & 0 & 1 & 72 & 0 \\
\hline Response $^{\mathrm{z}}$ & sen & sen & res & sen \\
\hline \multicolumn{5}{|l|}{ Mancozeb } \\
\hline $1 \mu \mathrm{g}$ & 102 & 95 & 93 & 98 \\
\hline $10 \mu \mathrm{g}$ & 94 & 100 & 94 & 100 \\
\hline $100 \mu \mathrm{g}$ & 28 & 0 & 0 & 0 \\
\hline Response $^{\mathrm{z}}$ & res & res & res & res \\
\hline \multicolumn{5}{|l|}{ TPM + mancozeb } \\
\hline $1 \mu \mathrm{g}$ & 99 & 100 & 98 & 100 \\
\hline $10 \mu \mathrm{g}$ & 13 & 0 & 98 & 0 \\
\hline $100 \mu \mathrm{g}$ & 0 & 0 & 41 & 0 \\
\hline Response $^{\mathrm{z}}$ & sen & sen & res & sen \\
\hline
\end{tabular}

${ }^{y}$ Values are the percent growth of each fungicide treatment compared with the $0 \mathrm{ppm}$ control containing DMF ( $N, N$,-dimethyl formamide). Growth of the $H$. solani isolates was evaluated on V8 media every 2 weeks for 6 weeks and determined by Area Under Colony Expansion Curve (AUCEC) and represents colony expansion over time. AUCEC was used to determine fungicide sensitivity and was calculated by plotting the estimated proportion of growth against time and calculating the area under the plotted line as is done when determining the area under the disease progress curve (30). Means are from two subsamples per replicate with five replications, data were pooled from repeated experiments. Percent growth is the treatment AUCEC in relation to the DMF control AUCEC.

${ }^{\mathrm{z}}$ Response indicates sensitivity to thiophanate-methyl (TPM) and mancozeb, sensitive $=$ sen and resistant $=$ res. Sensitivity was determined by a decrease in colony growth by $50 \%$ or more $\left(\mathrm{EC}_{50}\right)$ at the TPM and mancozeb treatment rate of $10 \mu \mathrm{g} / \mathrm{ml}$ when compared with colonies on agar amended with equal amounts of DMF. tested for TPM sensitivity, only isolate 25 was resistant. It was also resistant to TBZ, which is not surprising since both fungicides are members of the same fungicide group (benzimidazoles). Isolate 25 was collected from seed originating from North Dakota.

Kawchuk et al. (17) and Merida and Loria (21) both noted that isolates from the same tuber lot generally had the same TBZ sensitivity, but Merida and Loria reported both resistant and sensitive isolates from the same seed lot. Results from the current study support the existence of differing sensitivity within the same seed lot. However, the work reported here found resistant and sensitive isolates can be obtained from the same tuber (isolates 12a and 12b). Isolate phenotypic and genotypic differences within a population or microgeographical location are not uncommon. McDermott et al. (19) compared 163 isolates of Rhynchosporium secalis from two experimental barley populations using genetic, phenotypic, and pathogenicity tests. Of the 163 isolates sampled, 19\% were unique. Similar results of isolate differences were found by Burdon and Roelfs (2) in asexual populations of Puccinia graminis. Isolate differences have also been determined within a lesion. McDonald and Martinez (20) used DNA restriction fragment length polymorphisms among Mycosphaerella graminicola (anamorph Septoria tritici) isolates to determine that 8 out of 31 comparisons had different pycnidial isolates in the same lesion.

While isolate pairs $1 \mathrm{a}$ and $1 \mathrm{~b}$ and $5 \mathrm{a}$ and $5 \mathrm{~b}$ did not differ in their sensitivity to TBZ, they did differ morphologically. These isolates originated from the same tuber but from different colonies. Therefore, it seems reasonable to suggest that there are different genotypes in the population of $H$. solani in the Columbia Basin of Washington and Oregon. There is no evidence to suggest sexual recombination, and little is known about the mutation rate of $H$. solani. However, due to the large amount of seed shipped into Washington and Oregon each year from several states and Canadian provinces, the phenotypic diversity most likely originated via seed.

\section{ACKNOWLEDGMENTS}

We thank the Washington and Oregon State Potato Commissions for financial support of this project. Our special thanks to Tom Cummings for assistance with data collection and analysis. PPNS no. 0433, Department of Plant Pathology, College of Agricultural, Human, and Natural Resource Sciences, Agricultural Research Center project No. 0678, Washington State University, Pullman, WA 99164-6430.

\section{LITERATURE CITED}

1. Bain, P. S., Bisht, V. S., and Benard, D. A. 1996. Soil survival and thiabendazole sensitivity of Helminthosporium solani isolates from Alberta, Canada. Potato Res. 39:23-30.

2. Burdon, J. J., and Roelfs, A. P. 1985. The 
effect of sexual and asexual reproduction on the isozyme structure of populations of Puccinia graminis. Phytopathology 75:1068-1073.

3. Cayley, G. R., Hide, G. A., Read, P. J., and Dunne, Y. 1983. Treatment of potato seed and ware tubers with imazalil and thiabendazole for control of silver scurf and other storage diseases. Potato Res. 26:163-173.

4. Dashwood, E. P., Fox, R. A., and Perry, D. A. 1992. Effect of inoculum source on root and tuber infection by potato blemish disease fungi. Plant Pathol. 41:215-223.

5. Delp, C. J. 1980. Coping with resistance to plant disease. Plant Dis. 64:652-657.

6. Denner, F. D. N., Millard, C. P., Geldenhuys, A., and Wehner, F. C. 1997. Treatment of seed potatoes with prochloraz for simultaneous control of silver scurf and black dot on progeny tubers. Potato Res. 40:221-227.

7. Dow, A. I., Halvorson, A. R., and Thornton, R. E. 1974. Fertilizer guide to irrigated potatoes. Wash. State Univ. FG-7.

8. Firman, D. M., and Allen, E. J. 1995. Transmission of Helminthosporium solani from potato seed tubers and effects of soil conditions, seed inoculum and seed physiology on silver scurf disease. J. Agric. Sci. 124:219:234.

9. Frazier, M. J., Shetty, K. K., Kleinkopf, G. E., and Nolte, P. 1998. Management of Silver Scurf (Helminthosporium solani) with fungicide seed treatments and storage practices. Am. J. Potato Res. 75:129-135.

10. Goth, R. W., and Webb, R. E. 1983. Maintenance and growth of Helminthosporium solani. Am. Potato J. 60:281-287.

11. Hall, S. M., and Hide, G. A. 1992. Fungicide treatment of seed tubers infected with thiabendazole-resistant Helminthosporium solani and Polyscytalum pustulans for controlling silver scurf and skin spot on stored progeny tubers. Potato Res. 35:143-147.

12. Hide, G. A., and Hall, S. M. 1993. Develop- ment of resistance to thiabendazole in Helminthosporium solani (silver scurf) as a result of potato seed tuber treatment. Plant Pathol. 42:707-714.

13. Hide, G. A., Hall, S. M., and Boorer, K. J. 1988. Resistance to thiabendazole in isolates of Helminthosporium solani, the cause of silver scurf disease of potatoes. Plant Pathol. 37:377-380.

14. Jeger, M. J., Hide, G. A., Van Den Boogert, P. H. J. F., Termorshuizen, A. J., and Van Baarlen, P. 1996. Pathology and control of soil-borne fungal pathogens of potato. Potato Res. 39:437-469.

15. Jellis, G. J., and Taylor, G. S. 1977. Control of silver scurf (Helminthosporium solani) disease of potato with benomyl and thiabendazole. Ann. Appl. Biol. 86:59-67.

16. Jellis, G. J., and Taylor, G. S. 1977. The development of silver scurf (Helminthosporium solani) disease of potato. Ann. Appl. Biol. 86:1928

17. Kawchuk, L. M., Holley, J. D., Lynch, D. R., and Clear, R. M. 1994. Resistance to thiabendazole and thiophanate-methyl in Canadian isolates of Fusarium sambucinum and Helminthosporium solani. Am. Potato J. 71:185-192.

18. Lennard, J. H. 1980. Factors affecting the development of silver scurf (Helminthosporium solani) on potato tubers. Plant Pathol. 29:87-92.

19. McDermott, J. M., McDonald, B. A., Allard, R. W., and Webster, R. K. 1989. Genetic variability for pathogenicity, isozyme, ribosomal DNA and colony color variants in populations of Rhynchosporium secalis. Genetics 122:561565 .

20. McDonald, B. A., and Martinez, J. P. 1990. DNA restriction fragment length polymorphisms among Mycosphaerella graminicola (anamorph Septoria tritici) isolates collected from a single wheat field. Phytopathology
80:1368-1373.

21. Merida, C. L., and Loria, R. 1994. Comparison of thiabendazole-sensitive and -resistant Helminthosporium solani isolates from New York. Plant Dis. 78:187-192.

22. Merida, C. L., and Loria, R. 1994. Survival of Helminthosporium solani in soil and in vitro colonization of senescent plant tissue. Am. Potato J. 71:591-598.

23. Ogilvy, S. E. 1992. The use of pre-planting and post-harvest fungicides for the control of silver scurf in ware potatoes. Aspects Appl. Biol 33:151-158.

24. Olivier, C., Halseth, D. E., Mizubuti, E. S. G., and Loria, R. 1998. Postharvest application of organic and inorganic salts for suppression of silver scurf on potato tubers. Plant Dis. 82:213-217.

25. Read, P. J., and Hide, G. A. 1984. Effects of Silver Scurf (Helminthosporium solani) on seed potatoes. Potato Res. 27:145-154.

26. Rodriguez, D. A., Secor, G. A., and Gudmestad, N. C. 1993. Effect of planting and harvest date on incidence of silver scurf. (Abstr.) Am. Potato J. 70:836.

27. Rodriguez, D. A., Secor, G. A., Gudmestad, N. C., and Francl, L. J. 1996. Sporulation of Helminthosporium solani and infection of potato tubers in seed and commercial storages. Plant Dis. 80:1063-1070.

28. Rodriguez, D. A., Secor, G. A., Gudmestad, N. C., and Grafton, K. 1995. Screening tuberbearing solanum species for resistance to Helminthosporium solani. Am. Potato J. 72:669-679.

29. Tsror, L., and Peretz-Alon, I. 2004. Control of Silver Scurf on Potato by Dusting or Spraying Seed Tubers with Fungicides Before Planting. Am. J. Potato Res. 81:291-294.

30. Vanderplank, J. E. 1963. Plant Diseases: Epidemics and Control. Academic Press, New York. p. 349. 